\title{
Chitinolytic Assay and Identification of Bacteria Isolated from Shrimp Waste Based on 16S rDNA Sequences
}

\author{
Imanda N. Setia, Suharjono \\ Biology Department, Faculty of Mathematics and Natural Sciences, Brawijaya University, Malang, Indonesia \\ Email: imandanurulsetia@yahoo.com, calistus@ub.ac.id
}

Received 23 June 2015; accepted 19 July 2015; published 22 July 2015

Copyright (C) 2015 by authors and Scientific Research Publishing Inc.

This work is licensed under the Creative Commons Attribution International License (CC BY).

http://creativecommons.org/licenses/by/4.0/

(c) (i) Open Access

\begin{abstract}
Shrimp waste contains $20 \%-60 \%$ chitin and possible to be source of chitinolytic bacteria. Chitinolytic bacteria are capable of hydrolyzing of chitin progressively to produce $\mathrm{N}$-acetylglucosamine monomer which can be used to overcome the shrimp waste. The objectives of this research were to identify species of bacteria with high activity of chitin degradation in shrimp waste and to analyze their potency as chitin degradation agent. The research consists of screening of chitinolytic bacteria based on chitinolytic index, activity assay of chitinase using colorimetric method, and molecular identification of bacteria based on $16 \mathrm{~S}$ rDNA sequences. Two of eighteen isolates of chitinolytic bacteria (PBK 2 and SA 1.2 isolates) showed the highest chitinolytic index, which were 2.069 and 2.084, whereas chitinase activity was 0.213 and $0.219 \mathrm{U} / \mathrm{ml}$ respectively. Based on $16 \mathrm{~S}$ rDNA sequences, isolate of PBK 2 was identified as Acinetobacter johnsonii 3-1, whereas SA 1.2 was identified as Bacillus amyloliquefaciens GR53 with $99.78 \%$ similarity.
\end{abstract}

\section{Keywords}

Chitinolytic Bacteria, Chitin, Shrimp, Shrimp Waste

\section{Introduction}

Shrimp is one of the important export commodities of Indonesian fishery; therefore many fishery industries provide processed shrimp products to be exported [1]. According to Sachindra et al. [2], generally frozen shrimp are exported in headless form or without shells (peeled), so shrimp production will produce a lot of organic waste. Shrimp waste contains $20 \%$ - $60 \%$ of chitin as major structural component of shrimp exoskeletons and 
other crustacea, mollusca, insects, and arthropods [3]. Chitin is also contained in most of fungi cells walls [4].

Chitin $\left(\mathrm{C}_{6} \mathrm{H}_{9} \mathrm{O}_{4} \cdot \mathrm{NHCOCH}\right)_{\mathrm{n}}$ is linier homopolysaccharide which consists of 2000 - 3000 monomers of $\beta-1,4$ linked N-acetyl-D-glucosamine). It is second-most abundant organic compound after cellulose [5]. Chitin is water insoluble and degraded naturally by microorganism such as chitinolytic bacteria using chitinase as hydrolytic enzyme [6] [7]. Chitinase is secreted to outer cells of bacteria and bind to chitin molecule to break chitin into $\mathrm{N}$-acetylglucosamine monomer [8]. Chitinolytic bacteria are capable of producing chitinase and hydrolyzing chitin progressively to produce GINAc (N-acetylglucosamine) monomer through enzymatic reaction [9]. These bacteria are found in soil, marine, lake, or chitinous waste such as industrial shrimp waste [10]. The objectives of this research were to identify species of bacteria with high activity of chitin degradation in shrimp waste based on $16 \mathrm{~S}$ rDNA and to analyze their potency as chitin degradation agent.

\section{Materials and Methods}

\subsection{Preparation of Colloidal Chitin}

Colloidal chitin was prepared according modified method as described by Faramarzi et al. [11]. Ten grams of chitin from shrimp shell flake were added into $100 \mathrm{ml}$ concentrated $\mathrm{HCl}$ (37\%) and kept in vigorous stirring for $2 \mathrm{~h}$ at room temperature or until chitin completely dissolved. The suspension was precipited by slowly added to $500 \mathrm{ml}$ of ice-cold absolute ethanol. Then $\mathrm{pH}$ of suspension was neutralized with $10 \mathrm{~N} \mathrm{NaOH}$. Suspension was centrifuged at $8000 \mathrm{rpm}$ for $10 \mathrm{~min}$ and the precipitate was ready to use as medium substrate.

\subsection{Sample Collection and Isolation of Chitinolytic Bacteria}

Solid waste (shrimp-shells) and shrimp wastewater aseptically collected from PT. Bumi Menara Internusa (08 $\left.13^{\prime} 03.08 " \mathrm{~S}, 112^{\circ} 44^{\prime} 49.1^{\prime \prime E}\right)$. Chitinolytic bacteria were isolated using spread plate method in CCA medium (Colloidal Chitin Agar) which consist of (g/L): $\mathrm{Na}_{2} \mathrm{HPO}_{4}$ (6); $\mathrm{KH}_{2} \mathrm{PO}_{4}(3) ; \mathrm{NH}_{4} \mathrm{Cl}$ (1); $\mathrm{NaCl}$ (0.5); yeast extract (0.05); agar (15) and colloidal chitin $0.5 \%(\mathrm{w} / \mathrm{v})$. Chitinolytic bacteria showed by clear zones surrounding colonies after $72 \mathrm{~h}$ of incubations at $30^{\circ} \mathrm{C}[8]$.

\subsection{Primary Screening of Chitinolytic Bacteria}

Primary screening was performed by disc diffusion modified method of Jiang [12] with three replications. A loopfull of bacteria inoculated in colloidal chitin broth containing 1\% colloidal chitin (w/v) and incubated for 24 h, $180 \mathrm{rpm}, 30^{\circ} \mathrm{C}$ [9]. Cultures of each isolate $\left(10^{7}\right.$ cells $\left./ \mathrm{ml}\right)$ was inoculated to sterile paper disc $(d=5 \mathrm{~mm}$, Whatmann filter paper No. 1) and put on medium agar surface supplemented with $1 \%$ colloidal chitin and incubated at $30^{\circ} \mathrm{C}$ [5]. Chitinolytic index data (ratio of clear zone and colony sizediameter) were recorded up to 7 days incubations [11]. Data of chitinolytic index were analyzed using analysis of variance (ANOVA) that continued with Games-Howel test $(\alpha=0.05)$ using SPSS for Windows V.16.

\subsection{Secondary Screening of Chitinolytic Bacteria}

Chitinase activity was determined using colorimetric method as described by Monreal and Reese [13] with three replications. Reaction mix consist of $1 \mathrm{ml}$ crude enzyme, $1.5 \mathrm{ml}$ of $1 \%$ colloidal chitin substrate in $200 \mathrm{mM}$ potassium phosphate buffer ( $\mathrm{pH}$ 6.0). The mixture was incubated at $30^{\circ} \mathrm{C}$ for $2 \mathrm{~h}$, boiled for 10 min to stop reaction, and centrifuged at $8000 \mathrm{rpm}$ for $20 \mathrm{~min}$. Then $1 \mathrm{ml}$ of test supernatant was added to $1 \mathrm{ml}$ of DNS (Dinitrosalicylic Acid), boiled for 5 min, and cooling down at room temperature. Released of GlcNAc (Nacetylglucosamine) was measured at $540 \mathrm{~nm}$. Standard curve of GlcNAc was plotted between GlcNAc concentration and GlcNAc absorbance. One unit of chitinase activity was described as the amount of enzyme which liberate $1.0 \mathrm{mg}$ GlcNAc per hour from chitin substrate under reaction condition. Data of chitinase activity were analyzed with Independent Sample T-test analysis statistic $(\alpha=0.05)$ using SPSS for Windows V.16.

\subsection{DNA Extraction of Chitinolytic Bacteria}

Two loopfull of chitinolytic bacteria was inoculated in Luria Bertani broth (Merck) and incubated for 24 hours, $120 \mathrm{rpm}, 30^{\circ} \mathrm{C}$. Whole genome extraction was carried out by Ausubel method [14]. 


\subsection{Amplification and Sequencing of 16S rDNA}

Sequences of 16S rDNA was amplified with universal primers 27F (5'GAGAGTTTGATCCTGGCTCAG3') and 1492R (5'CTACGGCTACCTTGTTACGA3') [15]. PCR master mix solution was prepared as described by Intron Biotechnology [16] as shown in Table 1, PCR reaction condition was based on method of Mulhardt [17] and Zarei et al. [18] as shown in Table 2. Amplicon of $16 \mathrm{~S}$ rDNA was separated by $1 \%$ electrophoresis agarose gels [10]. Amplicon of partial 16S rDNA was purified and sequenced for further process in First Base, Malaysia. Sequencing was carried out using same primers. Partial sequences was matched with nucleotide database in Gene Bank (http://www.ncbi.nlm.nih.gov) using BLASTN to identify bacteria isolate based on highest \% nucleotide similarity.

\subsection{Phylogeny Tree Construction}

Sequences of 16S rDNA was matched with sequences of reference strains (Table 3) in GenBank database (http://www.ncbi.nlm.nih.gov) and was aligned through Clustal W Multiple Alignment tool. Phylogeny tree was constructed using phylogeny tool in MEGAV.6 program, inferenced using Maximum Likelihood method, and analyzed with evolutionary distance using Tamura-Nei model [19]. Outgroup of phylogeny tree was choosed according to similar genus and has been reported as chitinolytic bacteria.

\section{Results and Disscussion}

\subsection{Chitinase Activity of Shrimp Waste Chitinolytic Bacteria}

Eighteen isolates with different morphology of colonies were isolated from shrimp waste, 14 isolates from wastewater, and 4 isolates from shrimp-shells waste. Wastewater aeration can support more bacterial growth. During aeration, bacteria will grow and survive by using oxygen to breakdown wastewater compound and combine with organic matter in wastewater to form an activated sludge [20]. Based on primary screening, two of 18 isolates showed the highest chitinolytic index (CI > 2), there were isolates PBK 2 and SA 1.2 with chitinolytic index 2.069 dan 2.084 respectively. Clear zone surrounding the colony indicates chitinase activity to breakdown chitin compound in medium [8]. From primary screening result, isolate PBK 2 and SA 1.2 were selected for chitinase activity assay.

As shown in Figure 1, isolate PBK 2 and SA 1.2 showed almost similar chitinase activity $(0.213$ and 0.219 $\mathrm{U} / \mathrm{ml}$ respectively). Chitinase activity is amount of product which is produced from chitin substrate derivation.

\begin{tabular}{ccc}
\hline Table 1. PCR master mix composition. & & \\
\hline Composition & Volume $(\mu \mathrm{l})$ & Concentration \\
\hline $\mathrm{ddH}_{2} \mathrm{O}$ & 6 & - \\
2x PCR Master $M i x\left(\mathrm{i}-\mathrm{Taq}^{\mathrm{TM}}\right)$ & 15 & $10 \mathrm{pmol} / \mu \mathrm{l}$ \\
Primer 1 (27f) & 3 & $10 \mathrm{pmol} / \mu \mathrm{l}$ \\
Primer 2 (1495r) & 3 & $1 \mu \mathrm{g}$ \\
\hline DNA template & 3 & \\
\hline
\end{tabular}

Table 2. PCR reaction condition.

\begin{tabular}{ccc}
\hline Reaction & Temperature $\left({ }^{\circ} \mathrm{C}\right)$ & Time (minutes) \\
\hline Pre-denaturation & 94 & 5 \\
35 cycles : denaturation & 94 & 0.5 \\
Annealing & 55 & 0.5 \\
Extension & 72 & 1.5 \\
Post extension & 72 & 5 \\
\hline
\end{tabular}


Table 3. Reference strains for phylogeny construction based on 16S rDNA sequences.

\begin{tabular}{|c|c|c|c|}
\hline No. & Acession number & Species & Strain \\
\hline 1 & EU594557 & Acinetobacter johnsonii & $3-1$ \\
\hline 2 & JQ039983 & Acinetobacter johnsonii & YNB71 \\
\hline 3 & EU730929 & Acinetobacter johnsonii & 178 \\
\hline 4 & KJ569367 & Acinetobacter schindleri & C47EM \\
\hline 5 & KJ569366 & Acinetobacter schindleri & EM21 \\
\hline 6 & NR025412 & Acinetobacter schindleri & LUH5832 $^{\mathrm{T}}$ \\
\hline 7 & AB859678 & Acinetobacter schindleri & MTCC 9827 \\
\hline 8 & FJ373024 & Acinetobacter schindleri & W1-2 \\
\hline 9 & JX315564 & Acinetobacter schindleri & URT27 \\
\hline 10 & HQ689693 & Acinetobacter schindleri & IBP-SL13 \\
\hline 11 & Z93438 & Acinetobacter junii & ATCC $17908^{\mathrm{T}}$ \\
\hline 12 & Z93434 & Acinetobacter calcoaceticus & ATCC $23055^{\mathrm{T}}$ \\
\hline 13 & EF423606 & Bacillus amyloliquefaciens & ATCC 15841 \\
\hline 14 & EF423604 & Bacillus amyloliquefaciens & ATCC 21556 \\
\hline 15 & EF423607 & Bacillus amyloliquefaciens & ATCC 21770 \\
\hline 16 & NR118950 & Bacillus amyloliquefaciens & ATCC $23350^{\mathrm{T}}$ \\
\hline 17 & DQ993675 & Bacillus amyloliquefaciens & ATCC 49763 \\
\hline 18 & EF423605 & Bacillus amyloliquefaciens & BCRC 11266 \\
\hline 19 & EF433406 & Bacillus amyloliquefaciens & BCRC $11601^{\mathrm{T}}$ \\
\hline 20 & KJ937782 & Bacillus amyloliquefaciens & GR53 \\
\hline 21 & KC692168 & Bacillus amyloliquefaciens & ML265 \\
\hline 22 & AB679995 & Bacillus amyloliquefaciens & NBRC 3037 \\
\hline 23 & NR114581 & Bacillus thuringiensis & ATCC $10792^{\mathrm{T}}$ \\
\hline
\end{tabular}

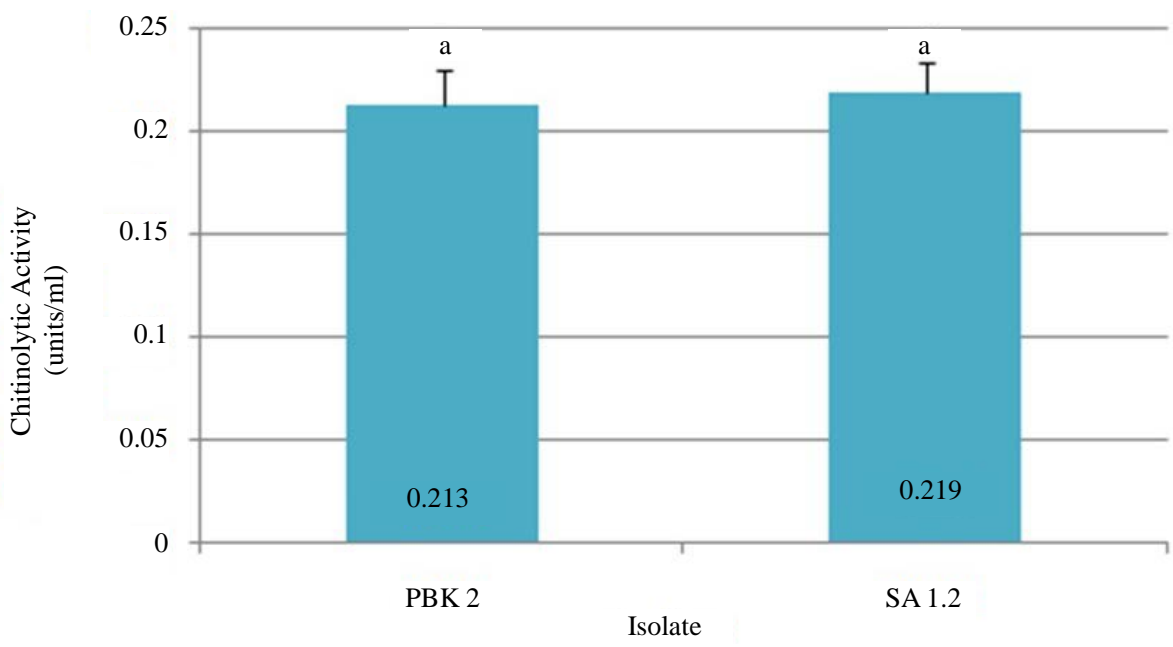

Figure 1. Chitinase activity of PBK 2 and SA 1.2 isolate at pre-stationary phase of growth. 
Chitin is substrate which can induce exochitinase and endochitinase formation in microorganisms [21]. Rate of chitin waste degradation is influenced by chitinase activity, enviromental factors, indigenous microorganisms metabolism from carbon utilization as source of energy, protein synthesis, and releasing cell metabolism products [22].

Chitinase activity of microorganisms is different from each other depends on various factors such as time of enzymatic reaction, enzyme and substrate concentation, incubation time, and $\mathrm{pH}$ of medium [23]. Based on Lamine et al. [24] Serratia marcescens DSM $30121^{\mathrm{T}}$ has the highest chitinase activity $(0.556 \mathrm{U} / \mathrm{ml})$ when was cultured in medium containing $1 \%$ colloidal chitin concentration, at $30^{\circ} \mathrm{C}$, and $\mathrm{pH}$-value of 6 . Based on Saleem et al. [25] Bacillus thuringiensis isolate CMBL-Bt4 has the highest chitinase activity than 12 of others Bacillus thuringiensis $(0.23 \mathrm{U} / \mathrm{ml})$ after 4 days incubation at $37^{\circ} \mathrm{C}$ with $\mathrm{pH}$ value 7 for culture medium. Meanwhile, according to Saadoun et al. [26] isolate Streptomyces sp. $\mathrm{S}_{242}$ has the highest chitinase activity $(0.162 \mathrm{U} / \mathrm{ml})$ after 4 days incubation at $30^{\circ} \mathrm{C}$ with $\mathrm{pH}$ value 7 for culture medium.

\subsection{Taxonomy of Isolate PBK 2 and SA 1.2 Based on 16S rDNA Sequences}

Amplicon 16S rDNA sequences of isolate PBK 2 and SA 1.2 on 1\% agarose gels showed in 1500 bp (Figure 2). According to Nocker et al. [27] amplification 16S rDNA sequences of bacteria can produce 1500 - 1600 bp amplicon. Analysis of DNA sequences showed that isolate of PBK 2 was identified as Acinetobacter johnsonii 3-1, whereas SA 1.2 identified as Bacillus amyloliquefaciens GR53 with 99.78\% similarity respectively. Identification criteria at species level consist of strains which have $16 \mathrm{~S}$ rDNA sequences similarity more than $97 \%$, whereas sequences similarity more than $99 \%$ include in strain level [28].

Genus Acinetobacter and Bacillus were dominant bacteria in industrial wastewater especially in activated sludge flocs which involved in denitrification process with other genus such as Pseudomonas, Spirillum, Hyphomicrobium, Agrobacterium, Propionibacterium, Rhizobium, Corynebacterium, Cytophaga, Thiobacillus, and Alcaligenes [29]. Genus Acinetobacter is one of the phosporus accumulating microorganisms in wastewater such as Acinetobacter johnsonii [30] and Acinetobacter calcoaceticus [31]. Those bacteria will accumulate phosphorus as polyphosphate in granules in aerobic condition for cell synthesis and energy transportation, this stage can reduce phosphorus in wastewater $10 \%-30 \%$, then inorganic phosphate was released in anaerobic condition [29].

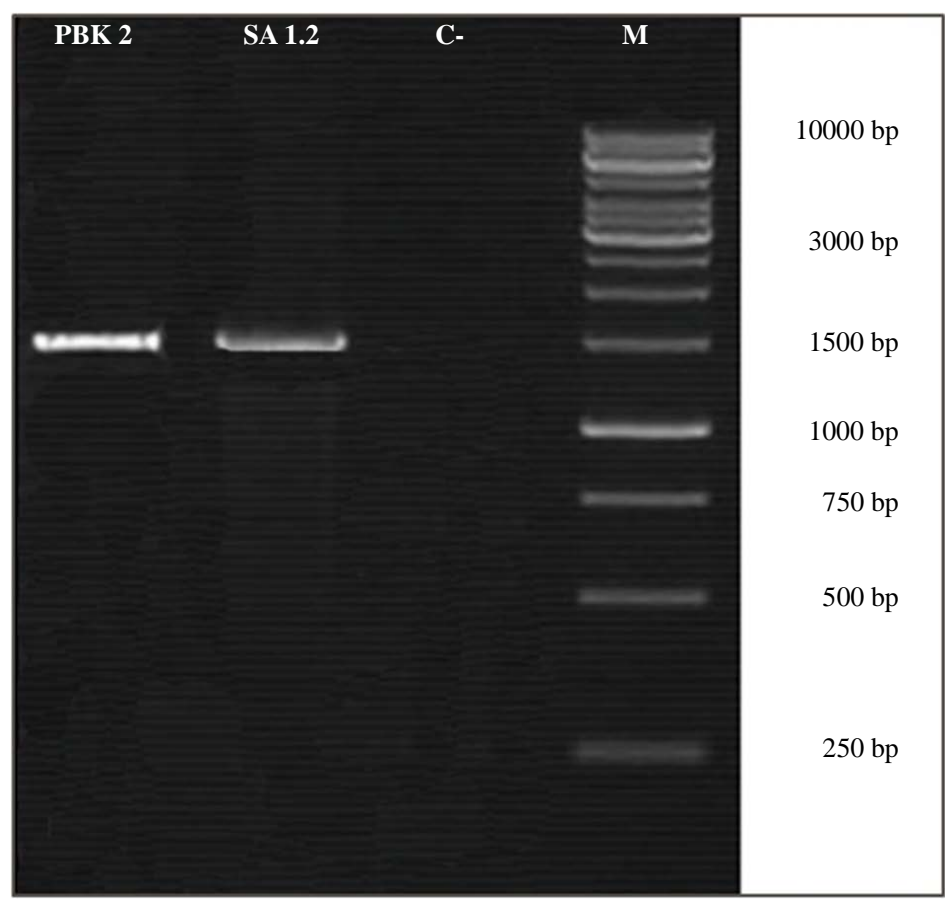

Figure 2. 16S rDNA purified amplicon of bacteria isolate compared with DNA Ladder Mix $1 \mathrm{~kb}(\mathrm{C}-=$ negative control, $\mathrm{M}=$ marker). 
As shown in Figure 3, isolate PBK 2 revealed close phylogenetic relationship with Acinetobacter johnsonii 3-1, whereas isolate SA 1.2 revealed close phylogenetic relationship with Bacillus amyloliquefaciens GR53. Based on microscopic characterization, isolate PBK 2 was Gram negative bacteria with coccibacil-shape and non-endospore forming accordance with Acinetobacter johnsonii, meanwhile isolate SA 1.2 was Gram positive, endospore forming, and rod-shape bacteria accordance with Bacillus amyloliquefaciens. Chitinase activity of Bacillus amyloliquefaciens was reported for the first time by Sabry [32]. Those bacteria can utilize shrimp shell
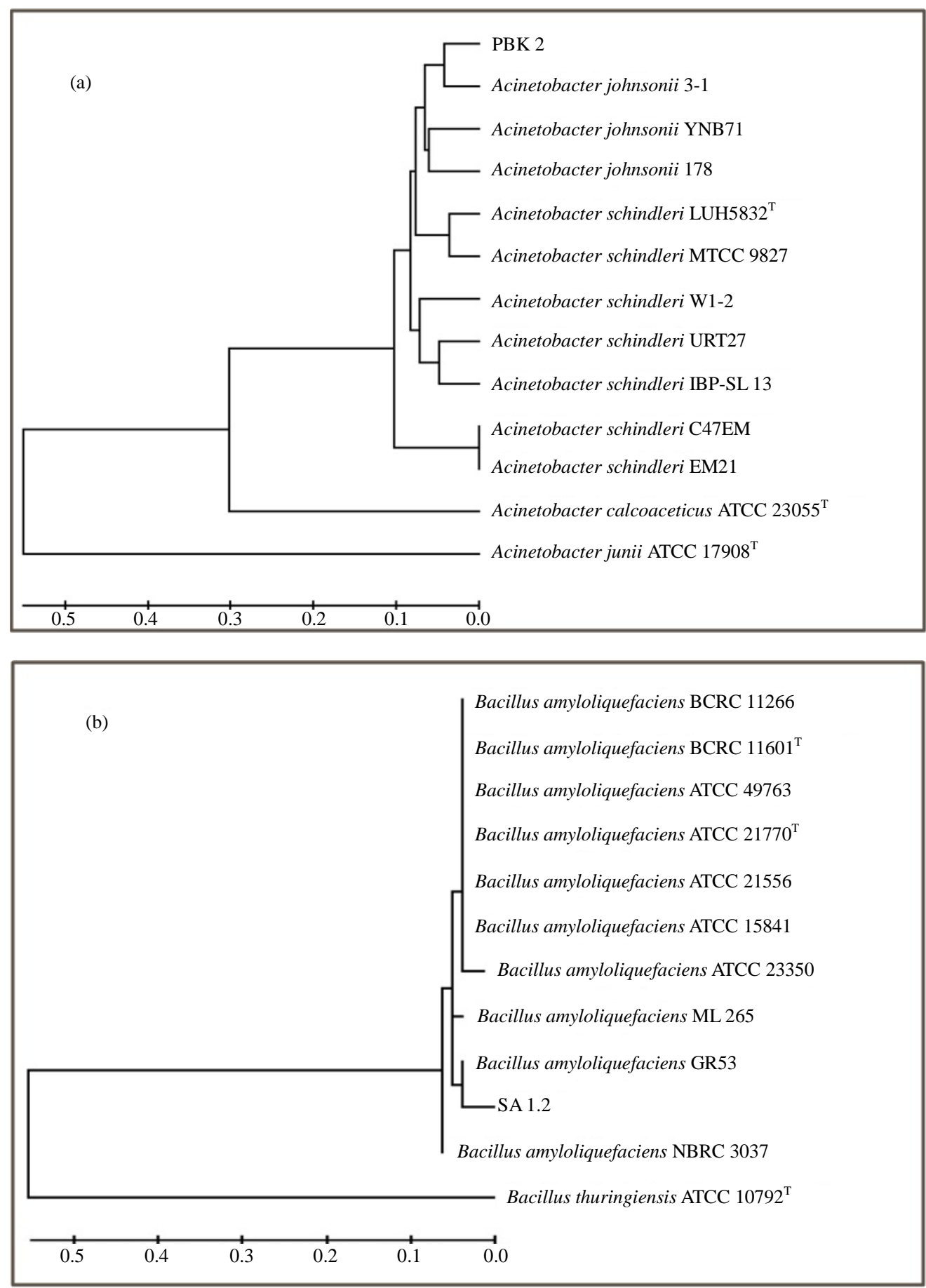

Figure 3. Phylogeny tree of isolate (a) PBK 2; (b) SA 1.2 compared with reference isolate using Maximum Likelihood algorithm with Tamura-Nei analysis method. 
to produce chitinase. According to Wang et al. [33]. Gram positive bacteria which identified as Bacillus amyloliquefaciens V656 based on analysis 16S rDNA can produced antifungal enzyme. This enzyme showed extracelullar chitinase activities against fungi. Acinetobacter johnsonii was reported as one of the chitinase-producing bacteria isolated from proximal intestine of Atlantic Salmon. Genus Acinetobacter and Bacillus were dominant enzyme-producing bacteria in the intestine of fish with chitin diet treatment [34].

\section{Conclusion}

Two of eighteen isolates of chitinolytic bacteria (PBK 2 and SA 1.2 isolates) showed the highest chitinolytic index, which were 2.069 and 2.084, whereas chitinase activity was 0.213 and $0.219 \mathrm{U} / \mathrm{ml}$ respectively. Based on 16S rDNA sequences, isolate of PBK 2 was identified as Acinetobacter johnsonii 3-1 with 99.78\% similarity, whereas SA 1.2 was identified as Bacillus amyloliquefaciens GR53 with $99.78 \%$ similarity.

\section{References}

[1] Irianto, H.E. (2011) Strategi Pengembangan Produk Indikasi Geografis berbasis Komoditas Perikanan Budaya. Prosiding Forum Inovasi Teknik Akuakultur.

[2] Sachindra, N.M., Bhaskar, N. and Mahendrakar, N.S. (2005) Carotenoids in Different Body Components of Indian Shrimps. Journal of Science Food and Agriculture, 85, 167-172. http://dx.doi.org/10.1002/jsfa.1977

[3] Haliza, W. and dan Suhartono, M.T. (2012) Karakteristik Kitinase dari Mikroba. Balai Teknologi Pascapanen Pertanian, 8.

[4] Knorr, D. (1984) Use of Chitinous Polymers in Food-A Challenge for Food Research and Development. Food Technology, 38, 85-97.

[5] Saima, M.K. and Roohi, I.Z. (2013) Isolation of Novel Chitinolytic Bacteria and Production Optimization of Extracellular Chitinase. Journal of Genetic Engineering and Biotechnology, 11, 39-46. http://dx.doi.org/10.1016/j.jgeb.2013.03.001

[6] Shanmugaiah, V., Mathivanan, N., Balasubramanian, N. and Manoharan, P.T. (2008) Optimization of Cultural Conditions for Production of Chitinase by Bacillus laterosporous MML2270 Isolated from Rice Rhizosphere Soil. African Journal of Biotechnology, 7, 2562-2568.

[7] Sato, K., Kato, Y., Fukamachi, A., Nogawa, M., Taguchi, G. and Shimosaka, M. (2010) Construction and Analysis of a Bacterial Community Exhibiting Strong Chitinolytic Activity. Bioscience, Biotechnology, and Biochemistry, 74, 636640. http://dx.doi.org/10.1271/bbb.90856

[8] Frändberg, E. (1997) Antifungal Compounds of Chitinolytic Bacteria from Grain Ecosystems. Doctor’s Dissertation.

[9] Al-Ahmadi, K.J., Yazdi, M.T., Najafi, M.F., Shahverdi, A.R., Faramarzi, M.A., Zarrini, G. and Behravan, J. (2008) Optimization of Medium and Cultivation Conditions for Chitinase Production by the Newly Isolated: Aeromonas sp. Biotechnology, 7, 266-272. http://dx.doi.org/10.3923/biotech.2008.266.272

[10] Jabeen, F. and Qazi, J.I. (2014) Isolation of Chitinase Yielding Bacillus cereus JF68 from Soil Employing an Edible Crab Shell Chitin. Journal of Science and Industrial Research, 73, 771-776.

[11] Faramarzi, M.A., Fazeli, M., Yazdi, M.T., Adrangi, S., Al-Ahmadi, K.J., Tasharrofi, N. and Mohseni, F.A. (2009) Optimization of Cultural Condition for Production Chitinase by Soil Isolate of Massilia timonae. Biotechnology, 8, 93-99. http://dx.doi.org/10.3923/biotech.2009.93.99

[12] Jiang, L. (2009) Comparison of Disk Diffusion, Agar Dilution, and Broth Microdilution for Antimicrobial Susceptibility Testing of Five Chitosans. Master's Thesis, Fujian Agricultural and Forestry University, Fuzhou.

[13] Monreal, J. and Reese, E.T. (1969) The Chitinase of Serratia marcescens. Canadian Journal of Microbiology, 15, 689696. http://dx.doi.org/10.1139/m69-122

[14] Ausubel, F.M., Brent, R., Kingston, R.E., Moore, D.D., Seidman, J.G., Smith, J.A. and Struhl, K. (1997) Current Protocols in Molecular Biology. John Wiley \& Sons, Inc., Hoboken.

[15] Suharjono, Sembiring, L., Subagja, Y. and Widayati, W.E. (2010) Sistematik Filogenetik Pseudomonas Strain Indigenous Pendegradasi Liniar Alkilbenzen Sulfonat. Biota, 15, 41-50.

[16] iNtRON Biotechnology (2011) 2x PCR Master mix Solution (i-Taq). http://eng.intronbio.com/

[17] Mulhardt, C. (2010) Molecular Biology and Genomics. Academic Press, Waltham.

[18] Zarei, M., Aminzadeh, S., Ghoroghi, A., Motalebi, A.A., Alikhajeh, J. and Daliri, M. (2012) Chitinase Isolated from Water and Soil Bacteria in Shrimp Farming Ponds. Iranian Journal of Fisheries Sciences, 11, 911-925.

[19] Tamura, K., Peterson, D., Peterson, N., Stecher, G., Nei, M. and Kumar, S. (2011) MEGA5: Molecular Evolutionary 
Genetics Analysis Using Maximum Likelihood, Evolutionary Distance, and Maximum Parsimony Methods. Molecular Biology and Evolution, 10, 2731-2739. http://dx.doi.org/10.1093/molbev/msr121

[20] Metcalf, L., Eddy, H.P., Tchobanoglous, G., Burton, F.L. and Stensel, H.D. (2003) Wastewater Engineering. 4th Edition, McGraw Hill International Editions, New York.

[21] Suryanto, D., Munir, E. and Yurnaliza (2005) Eksplorasi Bakteri Kitinolitik: Keragaman Genetik Gen Penyandi Kitinase pada Berbagai Jenis Bakteri dan Pemanfaatannya. USU Repository.

[22] Bailly, J.E. and Ollis, D.F. (1986) Biochemical Engineering Fundamentals. McGraw-Hill, New York.

[23] Keyhani, N.O. and Roseman, S. (1999) Physiological Aspect of Chitin Catabolism in Marine Bacteria. Biochimica et Biophysica Acta, 1473, 108-122. http://dx.doi.org/10.1016/S0304-4165(99)00172-5

[24] Lamine, B.M., Lamine, B.M. and Bouziane, A. (2012) Optimization of the Chitinase Production by Serratia Marcescens DSM $30121^{T}$ and Biological Control of Locusts. Journal of Biotechnology and Biomaterials, 2, 13-138. http://dx.doi.org/10.4172/2155-952X.1000133

[25] Saleem, F., Younas, A., Bashir, R., Naz, S., Munir, N. and Shakoori, A.R. (2014) Molecular Cloning and Characterization of Exochitinase A Gene of Indigenous Bacillus thuringiensis Isolates. Pakistan Journal of Zoology, 46, 1491-1501.

[26] Saadoun, I., Al-Omari, R., Jadarat, Z. and Ababneh, Q. (2009) Influence of Culture Conditions of Streptomyces sp. (Strain $\mathrm{S}_{242}$ ) on Chitinase Production. Polish Journal of Microbiology, 58, 339-345.

[27] Nocker, A., Lepo, J.E. and Synder, R.A. (2004) Influence of an Oyster Reef on Development of the Microbial Heterotrophic Community of an Estuarine Biofilm. Applied and Environtal Microbiology, 70, 6834-6845. http://dx.doi.org/10.1128/AEM.70.11.6834-6845.2004

[28] Drancourt, M., Bollet, C., Carlioz, A., Martelin, R., Gayral, J.P. and Raoult, D. (2000) 16S Ribosomal DNA Sequence Analysis of Large Collection of Enviromental and Clinical Unidentifiable Bacterial Isolate. Journal of Clinical Microbiology, 3, 3623-3630.

[29] Bitton, G. (2005) Wastewater Microbiology. 3rd Edition, John Wiley \& Sons, Inc., Canada. http://dx.doi.org/10.1002/0471717967

[30] Wiedmann-Al-Ahmad, M., Tichy, H.V. and Schön, G. (1994) Characterization of Acinetobacter Type Strains and Isolates Obtained from Wastewater Treatment Plants by PCR Fingerprinting. Applied and Environtal Microbiology, 60, 4066-4071.

[31] Ohtake, H., Takahashi, K., Tsuzuki, Y. and Toda, K. (1985) Uptake and Release of Phosphate by a Pure Culture of Acinetobacter calcoaceticus. Water Research, 19, 1587-1594. http://dx.doi.org/10.1016/0043-1354(85)90404-X

[32] Sabry, S.A. (1992) Microbial Degradation of Shrimp-Shell Waste. Journal of Basic Microbiology, 32, 107-111. http://dx.doi.org/10.1002/jobm.3620320207

[33] Wang, S., Shih, I., Liang, T. and Wang, C. (2002) Purification and Characterization of Two Antifungal Chitinases Extracellularly Produced by Bacillus amyloliquefaciens V656 in a Shrimp and Crab Shell Powder Medium. Journal of Agricultural and Food Chemistry, 50, 2241-2248. http://dx.doi.org/10.1021/jf010885d

[34] Askarian, F., Zhou, Z., Olsen, R.E., Sperstad, S. and Ringø, E. (2012) Culturable Autochthonous Gut Bacteria in Atlantic Salmon (Salmo salar L.) Fed Diets with or without Chitin. Characterisation by 16S rRNA Gene Sequencing, Ability to Produce Enzymes and in Vitro Growth Inhibition of Four Fish Pathogens. Aquaculture, 326, 1-8. http://dx.doi.org/10.1016/j.aquaculture.2011.10.016 